\title{
Possible genetic influences in familial sarcoidosis
}

\author{
D. GERAINT JAMES \\ M.D., F.R.C.P. \\ K. H. G. Piyasena \\ M.B., M.R.C.P.
}

\author{
E. NeVILLE \\ M.B., M.R.C.P. \\ A. N. WALKER \\ M.B., B.S.
}

\author{
A. N. HAMLYN \\ M.B., M.R.C.P.
}

Royal Northern Hospital, London N.7

\begin{abstract}
Summary
Five families (three English, one Irish, one West Indian) contained eleven members with sarcoidosis, nine of whom have been investigated and followed. Their multisystem involvement and course was similar to that of other patients attending the Sarcoidosis Clinic at the Royal Northern Hospital. There were three brother-sister and two mother-offspring relations; it was not observed in a father-offspring relationship. It is noted that the course of one sister was considerably worse than that of her brother. The evidence suggests a recessive mode of inheritance for sarcoidosis susceptibility. Four other families are reported on in an Addendum.
\end{abstract}

WE have observed and followed five families in whom eleven persons had sarcoidosis. Nine of these have been investigated during 1960-1972 in the Sarcoidosis Clinic of the Royal Northern Hospital. Various relationships include brother-sister, mother-son, but not father-offspring in our series. We have compared the features of this series of familial sarcoidosis with our entire series for evidence of divergencies which may hallmark familial sarcoidosis. The findings suggest a recessive mode of inheritance which finds partial expression in affected homozygotes.

\section{Case reports (Fig. 1)}

\section{Family I}

Case 1. A 30-year-old Trinidadian woman presented with cervical lymphadenopathy, and enlarged hilar glands were noted in a chest X-ray. Mantouxtesting with Old Tuberculin (OT) $1 / 1000$ was initially positive but subsequently negative. She was Kveimpositive and biopsy of the neck gland yielded sarcoid tissue. Her lymphadenopathy resolved spontaneously and after 18 months the chest X-ray was clear.

Case 2. The brother of Case 1, aged 34, developed a swollen left ring finger in association with a cyst of the middle phalanx. Biopsy of the cyst yielded sarcoid tissue. A chest X-ray revealed bilateral hilar lymphadenopathy and the Mantoux test was negative to OT
$1 / 1000$. His chest radiograph also became normal in an 18-month interval, but the bone cyst persists.

A third sibling is known to have had pulmonary sarcoidosis in Canada but all efforts to trace him have so far failed.

\section{Family II}

Case 3. A 35-year-old married Englishwoman presented with bilateral iridocyclitis, left facial palsy, left post-auricular lymphadenopathy, bilateral hilar lymphadenopathy progressive to bilateral pulmonary infiltration, a maculopapular eruption, and splenomegaly. Skin biopsy yielded sarcoid tissue. The iridocyclitis responded to local steroid therapy, but diminution of the hilar lymphadenopathy was followed by progression to lung fibrosis despite oral steroids.

Case 4. The brother of Case 3, aged 31, also presented with an enlarged left postauricular lymph node and a chest $\mathrm{X}$-ray revealed bilateral hilar lymphadenopathy with bilateral pulmonary infiltration. Mantoux-testing was negative to OT $1 / 100$ and a Kveim test was negative; sarcoid tissue was obtained from a cervical node. Unlike his sister's protracted chronic course, his recovery was complete, the lymphadenopathy and chest X-ray abnormalities resolving within 3 years.

\section{Family III}

Case 5. A 55-year-old married Englishwoman presented with myxoedema, bilateral iridocyclitis, a maculo-papular rash on the legs and buttocks, bone cysts in the phalanges of both hands, and bilateral hilar lymphadenopathy. The Mantoux test was negative to OT $1 / 100$, and a Kveim test was also negative. Sarcoid tissue was obtained by skin biopsy. She responded to thyroxine and systemic steroids with resolution of all multi-system involvement in the course of 2 years. During the 12 years following resolution, she has, interestingly, had two transient recurrences of the skin eruption, for which there was no obvious precipitating factor. 
Family I

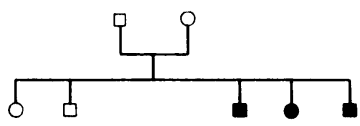

Family II

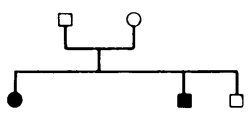

Fomily III

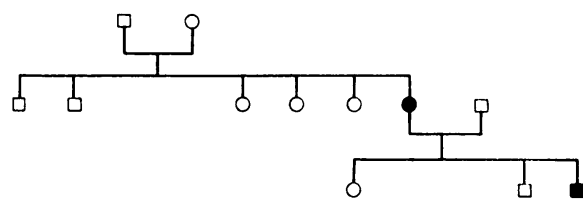

Family IV

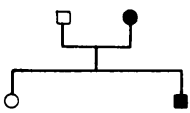

Fomily $\nabla$

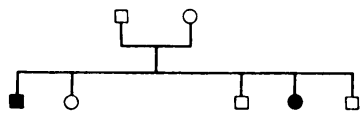

Fig. 1. Pedigrees of the five families showing the affected members. $\square$, male; $O$, female; $0, \square$, affected.

Case 6. The son of Case 5, aged 29, presented with bilateral hilar lymphadenopathy and peripheral pulmonary infiltration in both mid zones of a routine chest radiograph. Both the Kveim and Mantoux tests were negative. With the aid of oral steroids his chest radiograph became normal 2 years after initial presentation.

\section{Family IV}

Case 7. A 46-year-old married Englishwoman developed erythema nodosum and bilateral hilar lymphadenopathy. The Mantoux test was negative to OT $1 / 100$, and a Kveim test was positive. Erythema nodosum subsided within 1 month and the chest radiograph cleared in 9 months.

Case 8. The son of Case 7, aged 20, similarly developed erythema nodosum and bilateral hilar lymphadenopathy, with a negative Mantoux test to OT $1 / 1000$ and a positive Kveim test. His chest X-ray abnormalities persist and after 2 months he is still under review in the outpatient department.

\section{Family $V$}

Case 9. A 31-year-old Irishman complained of chest pain and effort dyspnoea. Chest X-ray showed bilateral hilar lymphadenopathy and liver biopsy yielded sarcoid granulomata. The Mantoux test was positive to OT $1 / 100$ and a Kveim test was positive. Increasing breathlessness coincided with the development of bilateral pulmonary mottling. His signs and symptoms resolved with the aid of steroids and 2 years later he remains well, with a normal chest radiograph.

His sister is known to have pulmonary sarcoidosis, but no details of her course are available.

Other members of these families were investigated without uncovering further examples of the disease (Fig. 1).

\section{Results \\ Family relationship}

Familial sarcoidosis has been noted in five families. A total of eleven persons are affected by sarcoidosis but adequate personally investigated data only extend to nine patients. The family relationships have been mother and son twice, brother and sister twice, and a brother and two affected sisters. It was not observed in a father-offspring in this series.

\section{Sex, race, age at onset}

The sexes were equal, as might be expected from our overall results in sarcoidosis (Table 1). One family of three patients (family I) were from Trinidad, another was Irish, and three families were English.

The age at presentation of sarcoidosis was not remarkable, occurring most commonly in the childbearing years of life. As in the overall series, twothirds presented below the age of 40 years.

\section{Presenting features}

The onset was similar to that of the overall series, presenting either at routine chest radiography or because of respiratory symptoms, skin or eye lesions (Table 1). Seven patients with familial sarcoidosis presented with bilateral hilar lymphadenopathy and another two also had pulmonary infiltration. These intrathoracic changes resolved spontaneously in three and with steroids in another three patients; there was progression to pulmonary fibrosis in one and the chest X-rays are unchanged in two patients.

\section{Extrathoracic manifestations}

The family cases showed evidence of multi-system involvement with similar extent and frequency of involvement as in our whole series (Table 2).

\section{Investigations}

The tuberculin test was negative in seven of nine $(87 \%)$ and the Kveim-Siltzbach test positive in five of nine $(71 \%)$ patients with familial sarcoidosis. Hyperglobulinaemia and hypercalciuria were noted infrequently (Table 1). Histological confirmation of sarcoid tissue biopsy was obtained in six of nine and the Kveim-Siltzbach test was positive in five of seven patients (Table 1). 
TABLE 1. Various features of multisystem sarcoidosis in whole series compared with those in familial sarcoidosis

\begin{tabular}{|c|c|c|c|c|}
\hline & \multicolumn{2}{|c|}{ Whole series } & \multicolumn{2}{|c|}{$\begin{array}{c}\text { Familial } \\
\text { sarcoidosis }\end{array}$} \\
\hline & No. & $\%$ & No. & $\%$ \\
\hline Total & 537 & 100 & 9 & 100 \\
\hline \multicolumn{5}{|l|}{ Sex } \\
\hline Women & 302 & 56 & 4 & 44 \\
\hline \multicolumn{5}{|l|}{ Race } \\
\hline White & 474 & 88 & 6 & 66 \\
\hline Negro & 2 & 1 & - & - \\
\hline Caribbean & 33 & 6 & 3 & 33 \\
\hline Other & 28 & 5 & - & - \\
\hline \multicolumn{5}{|l|}{ Age at presentation } \\
\hline Under 40 years & 358 & 67 & 6 & 66 \\
\hline Over 40 years & 179 & 33 & 3 & 33 \\
\hline \multicolumn{5}{|l|}{ Onset } \\
\hline Routine chest X-ray & 119 & 22 & 2 & 22 \\
\hline Respiratory symptoms & 49 & 9 & 2 & 22 \\
\hline Erythema nodosum & 150 & 28 & 2 & 22 \\
\hline Other skin lesions & 37 & 7 & 1 & 11 \\
\hline Ocular symptoms & 53 & 10 & 1 & 11 \\
\hline Bone cysts & 19 & 4 & 1 & 11 \\
\hline \multicolumn{5}{|l|}{ Presenting chest X-ray } \\
\hline Stage* 0 & 85 & 16 & - & - \\
\hline 1 & 243 & 45 & 7 & 77 \\
\hline 2 & 129 & 24 & 2 & 22 \\
\hline 3 & 80 & 14 & - & - \\
\hline \multicolumn{5}{|l|}{ Skin tests } \\
\hline Positive Kveim-Siltzbach & 384 & 82 & $5 / 7$ & 71 \\
\hline Negative tuberculin & 246 & 55 & $7 / 8$ & 87 \\
\hline \multicolumn{5}{|l|}{ Blood tests } \\
\hline Hyperglobulinaemia & 85 & 34 & 1 & 11 \\
\hline Hypercalcaemia & 57 & 24 & 1 & 11 \\
\hline \multicolumn{5}{|l|}{ Treatment } \\
\hline Cortiscosteroids & 185 & 34 & 4 & 44 \\
\hline No steroids & 352 & 66 & 5 & 55 \\
\hline \multicolumn{5}{|l|}{ Mortality } \\
\hline Due to sarcoidosis & 25 & 5 & - & - \\
\hline Due to other causes & 8 & $1 \cdot 5$ & 一 & - \\
\hline
\end{tabular}

* Stage $0=$ Clear chest radiograph; Stage $1=$ Bilateral hilar lymphadenopathy (BHL); Stage $2=$ BHL + Pulmonary infiltration; Stage $3=$ Diffuse pulmonary infiltration \pm fibrosis.

TABLE 2. Frequency of involvement of various tissues in sarcoidosis

\begin{tabular}{lrrrrr}
\hline & \multicolumn{2}{c}{ Whole series } & & \multicolumn{2}{c}{ Familial } \\
\cline { 2 - 3 } \cline { 5 - 6 } System & No. & $\%$ & & No. & $\%$ \\
\hline Lungs & 452 & 84 & 9 & 100 \\
Erythema nodosum & 167 & 31 & 2 & 22 \\
Lymph nodes & 153 & 29 & 3 & 33 \\
Eyes & 147 & 27 & 2 & 22 \\
Skin & 135 & 25 & 2 & 22 \\
Spleen & 62 & 12 & 1 & 11 \\
CNS & 38 & 7 & 0 & 0 \\
Parotid & 33 & 6 & 0 & 0 \\
Bone cysts & 19 & 4 & 2 & 22 \\
Total & 537 & 100 & 9 & 100 \\
\hline
\end{tabular}

\section{Genetic studies}

The sample consisted of the eleven cases of sarcoidosis in five kindreds; the pedigree and case numbers used are as outlined (Fig. 1).
Of the five siblings three were the offspring of unaffected parents and two of those of one affected parent and one unaffected. Those members of the sample suffering from sarcoidosis were considered to be of phenotype $\bar{s}$-sarcoidosis-susceptible, and those free from the disease phenotypic $S$-sarcoidosis-resistant. Assuming the presence of allelomorphic genes $S$ recessive to $S$ then we have genotypic Ss, - SS or SS for $\mathbf{S}$ and genotypic ss for $\bar{s}$. Matings I, II, IIIa and V could be $\mathbf{S s} \times$ Ss, Ss $\times$ SS or SS $\times$ SS, that is carrier $\times$ carrier, carrier $\times$ non-carrier or non-carrier $\times$ non-carrier. Similarly, IIIb and IV could be ss $\times$ Ss or ss $\times$ SS. The carrier state, in all recessive inheritance, is classically impossible to detect.

The methods of Hogben (1932) and Smith (1956), which allow for the truncated binomial distribution of recessives ( $\overline{\mathbf{s}})$ in affected families, were used to compare the observed distributions expected on the 
basis of probability. These were calculated for $\overline{\mathbf{S}} \times \overline{\mathbf{S}}$ and $\overline{\mathbf{s}} \times \overline{\mathbf{s}}$ matings separately (Table $3 \mathrm{a}, \mathrm{b}, \mathrm{c}, \mathrm{d}$ ).

The differences between the observed and expected number of recessives were tested against the standard error of estimate for statistical significance. For $\overline{\mathbf{S}} \times \overline{\mathrm{S}}$ matings this was $(8-9.064)=-1.064$ with s.e. $\sqrt{ } 3 \cdot 672=1.925$ and indicated good agreement with the hypothesis. For $\overline{\mathbf{S}} \times \overline{\mathbf{s}}$ matings it was $(3-3.440)=0.440$ with s.e. $\sqrt{ } 0.385=0.620$, which is again indicative of a good fit. Computing $\chi^{2}$ from the formula (observed - expected) ${ }^{2}$ variance yields values of 0.589 and 0.885 respectively, which summing and testing with 2 d.f. confirms no significant

TABle 3a. $\quad \overline{\mathbf{S}} \times \overline{\mathbf{S}}$ matings

\begin{tabular}{rcccc}
\hline $\begin{array}{c}\text { No. of } \\
\text { children } \\
\text { in family }\end{array}$ & $\begin{array}{c}\text { No. of } \\
\text { families } \\
\text { affected }\end{array}$ & $\begin{array}{c}\text { Observed } \\
\text { no. of } \\
\text { recessives }\end{array}$ & $\begin{array}{c}\text { Expected } \\
\text { no. of } \\
\text { recessives }\end{array}$ & Variance \\
\hline 3 & 1 & 2 & 1.714 & 0.490 \\
5 & 2 & 5 & 4.3025 & 1.803 \\
6 & 1 & 1 & 3.048 & 1.379 \\
Totals 14 & 4 & 8 & 9.064 & 3.672 \\
\hline
\end{tabular}

TABLE 3b. $\overline{\mathbf{S}} \times \overline{\mathbf{s}}$ matings

\begin{tabular}{rcccc}
\hline $\begin{array}{c}\text { No. of } \\
\text { children } \\
\text { in family }\end{array}$ & $\begin{array}{c}\text { No. of } \\
\text { families } \\
\text { affected }\end{array}$ & $\begin{array}{c}\text { Observed } \\
\text { no. of } \\
\text { recessives }\end{array}$ & $\begin{array}{c}\text { Expected } \\
\text { no. of } \\
\text { recessives }\end{array}$ & Variance \\
\hline 2 & 1 & 1 & $1 \cdot 143$ & $0 \cdot 122$ \\
3 & 1 & 2 & $2 \cdot 293$ & 0.263 \\
Totals 5 & 2 & 3 & 3.440 & 0.385 \\
\hline
\end{tabular}

departure from hypothesis $(0.3<P<0.5)$. However, no great reliance should be placed upon this statistic because of the small numbers involved.

It next became necessary to fit the recessive model to what is known about the incidence of sarcoidosis. None of the calculations so far required any knowledge of gene frequencies in the general population. Indeed, this is unknown as there is no way of testing for putative heterozygotes and it was therefore necessary to assume $\vec{s}$ frequency from estimates of the incidence of $\bar{s}$. In London these are about $19 / 100,000$ by mass chest radiography. From the Hardy-Weinberg formula for $p=S$ and $q=s, q=$ $0 \cdot 138$. From our knowledge of family size distribution in the sample it was possible to calculate the expected number of families containing at least one recessive child according to Hogben.

For $\overline{\mathbf{S}} \times \overline{\mathbf{s}}$ matings the observed difference 15.420 was larger than its standard error 3.990 and this represented a significant departure from hypothesis. However, when we consider $\overline{\mathbf{S}} \times \overline{\mathbf{S}}$ matings we find the difference between observed number of recessives (4) and expected number $(2 \cdot 835)$ less than the standard error $(2 \cdot 227)$, indicating adherence to the hypothesis in this case.

\section{Discussion}

Familial sarcoidosis is now recognized in Europe, Scandinavia, the United States and Japan, that is wherever sarcoidosis is frequently recognized. It was first noted by Martenstein (1923) in two affected sisters and reports have become increasingly common during the last 40 years (Table 4). Jorgensen (1963)

TABLE 3c. $\overline{\mathbf{S}} \times \overline{\mathbf{s}}$ matings

\begin{tabular}{ccccr}
\hline $\begin{array}{c}\text { No. of children } \\
\text { in family }\end{array}$ & $\begin{array}{c}\text { No. of children } \\
\text { in sample }\end{array}$ & $\begin{array}{c}\text { No. of families } \\
\text { with at least } \\
\text { 1 recessive }\end{array}$ & $\begin{array}{c}\text { No. of families } \\
\text { expected with at } \\
\text { least 1 recessive }\end{array}$ & Variance \\
\hline 1 & 11 & 0 & 1.340 & $1 \cdot 175$ \\
2 & 23 & 1 & 4.200 & 3.431 \\
3 & 19 & 1 & 3.991 & 4.424 \\
4 & 16 & 0 & 3.639 & 2.814 \\
5 & 11 & 0 & 2.587 & 1.975 \\
6 & 7 & 0 & 1.671 & 1.270 \\
Totals & 87 & 2 & 17.420 & 15.089 \\
\hline
\end{tabular}

TABLE 3d. $\overline{\mathbf{S}} \times \overline{\mathbf{S}}$ matings

\begin{tabular}{ccccc}
\hline $\begin{array}{c}\text { No. of children } \\
\text { in family }\end{array}$ & $\begin{array}{c}\text { No. of children } \\
\text { in sample }\end{array}$ & $\begin{array}{c}\text { No. of families } \\
\text { with at least } \\
\text { 1 recessive }\end{array}$ & $\begin{array}{c}\text { No. of families } \\
\text { expected with at } \\
\text { least 1 recessive }\end{array}$ & Variance \\
\hline 1 & 11 & 0 & $0 \cdot 160$ & $0 \cdot 158$ \\
2 & 23 & 0 & 0.594 & $0 \cdot 575$ \\
3 & 19 & 1 & 0.648 & $0 \cdot 458$ \\
4 & 16 & 0 & 0.649 & $0 \cdot 259$ \\
5 & 11 & 2 & 0.445 & $0 \cdot 405$ \\
6 & 7 & 1 & $0 \cdot 339$ & $0 \cdot 372$ \\
Totals & 87 & 4 & 2.835 & $2 \cdot 227$ \\
\hline
\end{tabular}


TABLE 4. Recorded examples of familial sarcoidosis

\begin{tabular}{|c|c|c|c|}
\hline Authors & Year & Relationship & Country \\
\hline Martenstein & 1923 & Two sisters & Germany \\
\hline Sellei and Berger & 1926 & Three sisters and two brothers & Vienna \\
\hline Dressler & $\begin{array}{l}1938 \\
1939\end{array}$ & Two brothers & Switzerland \\
\hline MacCormac & 1940 & Two sisters & London \\
\hline Richter and Richter & 1941 & Two sisters & Germany \\
\hline van Buchem & 1946 & Two brothers & Tilburg, Holland \\
\hline Robinson and Hahn & 1947 & $\begin{array}{l}\text { (1) Two brothers } \\
\text { (2) Four brothers }\end{array}$ & Baltimore \\
\hline Bickerstaff & 1949 & Two brothers & Ireland \\
\hline Sherer and Kelly & 1949 & Identical twins & U.S.A. \\
\hline Klingmuller & 1951 & $\begin{array}{l}\text { (1) Mother and son } \\
\text { (2) Two sisters }\end{array}$ & Germany \\
\hline Gilg & 1952 & Identical twins & Copenhagen \\
\hline Rogers and Netherton & 1954 & Identical twins & Cleveland \\
\hline Zwanenberg and Barry & 1955 & Three brothers and a sister & England \\
\hline Swirsky and Lowman & 1955 & Brother and sister & Connecticut, U.S.A. \\
\hline Moriarty & 1956 & Two sisters & England \\
\hline Warin & 1958 & $\begin{array}{l}\text { Mother and son } \\
\text { Brother and sister }\end{array}$ & England \\
\hline Kendig, Peacock and Ryburn & 1959 & Three sisters & Virginia, U.S.A. \\
\hline Baer & 1960 & Two brothers and two sisters & Texas, U.S.A. \\
\hline Kinoshita & 1966 & Mother and two daughters & Japan \\
\hline Beresford & 1970 & $\begin{array}{l}\text { (1) Mother and daughter } \\
\text { (2) Mother and son }\end{array}$ & England \\
\hline Wiman & 1973 & $\begin{array}{l}\text { Four families: (twenty-one } \\
\text { members; three generations) }\end{array}$ & Sweden \\
\hline Ito, Ogima and Kinoshita & 1973 & $\begin{array}{l}\text { Twelve famlies: (twenty-five } \\
\text { members affected) }\end{array}$ & Japan \\
\hline Present series & & $\begin{array}{l}\text { Five families: (eleven members } \\
\text { affected) }\end{array}$ & London \\
\hline
\end{tabular}

population. From the analysis of $\overline{\mathbf{S}} \times \overline{\mathbf{s}}$ matings in our

noted sarcoidosis in near relatives of $3.7 \%$ of patients with sarcoidosis in West Germany, an incidence higher than could have occurred by chance. It is more frequent in monozygotic rather than dizygotic twins. We noted it in brother-sister relations thrice and in mother-son offspring twice. It has been observed by Wiman (1973) in father-offspring once, but this is exceedingly rare.

Our five families comprised three English, one Irish and one West Indian family. It seems likely that there is a racial predisposition to familial sarcoidosis for Turiaf (personal communication) observes a greater incidence in half-breed French West Indians from Martinique than in the white French, with familial sarcoidosis in $1 \%$ of 365 white Europeans but in about $8 \%$ of natives of Martinique.

The clinical, radiological and other features of the disorder are similar in familial and sporadic sarcoidosis, but it is interesting to observe that the course of one sister was considerably worse than that of her brother (Family II). Wiman (1973) has also drawn attention to the poorer prognosis in the female compared with her brother, suggesting hormonal factors adversely affecting the course of the disease.

No genetic model has yet been proposed because of the rarity of both sporadic and familial sarcoidosis and the problem of identifying it in the general data, the observed discrepancy could be due to:

(a) difference of true gene frequency from assumed value;

(b) genetic lethality or sublethality of homozygote form;

(c) partial expression of the gene in homozygote form;

(d) errors of data collection, e.g. difficulty in tracing parents of probands, etc.

The presence of mild or subclinical forms of the disease not reported by the patient to his or her doctor would favour reasons (a), (c) and (d), but militate against (b). However, the possibility remains that subfertility could be an important factor in limiting the number of offspring of affected individuals and hence their chance of bearing recessives. The evidence suggests a recessive mode of inheritance for sarcoidosis susceptibility.

The British Thoracic and Tuberculosis Association (1973) conducted a survey and found fifty-nine families in Britain with more than one case of sarcoidosis. The most striking finding was the significant preponderance of like-sex over unlike-sex pairs among both siblings and parent-child associations. Their observed preponderance of monozygotic (4) over dizygotic (1) twin pairs concordant for 
sarcoidosis is also strongly suggestive of a genetic factor.

\section{References}

BAER, R.B. (1960) Familial sarcoidosis: epidemiological aspects with notes on a possible relationship to the chewing of pine pitch. Archives of Internal Medicine, 105, 60.

BERESFORD, O.D. (1971) Familial sarcoidosis. Japanese Journal of Chest Diseases, 30, 297.

BickerstafF, E.R. (1949) The familial aspects of sarcoidosis. British Journal of Tuberculosis, 43, 112.

British Medical Journal (1969) A case of sarcoidosis with cryptococcal meningitis. Clinico-pathological conference, 4, 729.

British Thoracic and Tuberculosis Association (1973) Familial association in sarcoidosis. Tubercle, 54, 87.

BuCHEM, F.S.P. VAN (1946) On morbid conditions of the liver and diagnosis of Besnier-Boeck-Schaumann Disease. Acta medica scandinavica, 124, 168.

Dressler, M. (1938) Boeck'sche Krankheit der Lungen bei Geschwistern. Schweizerische Medizinische Wochenschrift, $19,417$.

Dressler, M. (1939) Familiären Vorkommen des BesnierBoeck'schen Krankheit. Schweizerische Medizinische Wochenschrift, $20,269$.

GiLG, I. (1952) Boeck's sarcoid in identical twins. Acta Dermato-venerologica, Supplement, 29, 108.

Hogben, L. (1932) Genetic analysis of familial traits: matings involving one parent exhibiting trait determined by single recessive gene substitution with special reference to sexlinked conditions. Journal of Genetics, 25, 293.

Ito, Y., Ogima, I. \& Kinoshita, Y. (1974) Familial sarcoidosis in Japan. Proceedings of the VIth International Conference on Sarcoidosis. Tokyo University Press, p. 30.

JORGENSEN, G. (1963) Untersuchungen zur Genetik der Sarkoidose. Habil Schrift: Göttingen.

Kendig, E.L., Peacock, R.L. \& Ryburns, S. (1959) Sarcoidosis: Report of 3 cases in siblings under 15 years of age. New England Journal of Medicine, 260, 962.
Kinoshita, Y., Ogima, I. \& Aoki, S. (1966) 3 cases of sarcoidosis occurring in 2 generations of a family. Japanese Journal of Clinical Medicine, 24, 190.

Klingmuller, G. (1951) Der Morbus Boeck in der Familie. Dermatologica Wochenschrift, 124, 119.

MacCormac, H. (1940) Schaumann's disease in two sisters. Acta medica scandinavica, 103, 152.

MARTENSTEIN, H. (1923) Knochveranderungen bei lupus pernio. Zeitschrift für Haut- und Geschlechtskrankheiten. 7, 308.

MORIARTY, M.A .(1956) Sarcoidosis in siblings. Journal of the Irish Medical Association, 38, 7.

RichteR, R. \& RichteR, W. (1941) Beitrag zur Klinik der Besnier-Boeck-Schaumannscher Erkrankung. Dermatologica Wochenschrift, 113, 797.

Robinson, R.C.V. \& HAHN, R.D. (1947) Sarcoidosis in siblings. Archives of Internal Medicine, 80, 249.

Rogers, F.J. \& Netherton, E.W. (1954) Sarcoidosis in identical twins. Journal of the American Medical Association, 156, 974.

Sellei, J. \& Berger, M. (1926) Sarkoide Geschwülste in eine Familie. Archiv für Dermatologie und Syphilis, Wien, 150, 47.

Sherer, J.F. \& Kelly, R.T. (1949) Sarcoidosis in identical twins. New England Journal of Medicine, 240, 328.

Sмiтh, C.A.B. (1956) A test for segregation ratios in family data. Annals of Human Genetics, 20, 257.

Swirsky, M.Y. \& Lowman, R.N. (1955) Sarcoidosis in siblings. New England Journal of Medicine, 252, 476.

WARIN, R.P. (1958) Familial sarcoidosis. British Journal of Dermatology, 70, 250.

Wiman, L.G. (1973) Familial occurrence of sarcoidosis. Proceedings of the VIth International Conference on Sarcoidosis. Tokyo University Press, p. 22.

ZWANENBERG, D. VAN \& BARRY, M. (1955) A case of sarcoidosis and 3 cases of atypical tuberculosis in one family. Lancet, i, 483.

\section{Addendum}

Since this account was accepted, four further families have come to light, comprising a brother and sister, a mother and daughter, an uncle and niece on the paternal side, and finally a husband and wife.

\section{Family VI}

Case 12. A 26-year-old Englishman presented with bilateral hilar lymphadenopathy and extensive infiltration. Liver biopsy showed non-caseating granulomata and a Kveim-Siltzbach test was positive. He responded to steroids and is now fit with only some residual scarring in his chest radiograph.

Case 13. Seven years later, the married sister of Case 12, aged 35, also presented with bilateral hilar lymphadenopathy and pulmonary mottling. The Kveim-Siltzbach test was positive and Heaf test negative. There was spontaneous resolution of the chest X-ray abnormality.

\section{Family VII}

Case 14. A 28-year-old Englishwoman presented with pulmonary infiltration associated with a negative tuberculin test in 1937; the lung changes cleared spontaneously in 18 months. She eventually died of hypertensive renal disease in 1967. There was no evidence of nephrocalcinosis.

Case 15. The daughter of Case 14, also when aged 28 years, presented with bilateral pulmonary infiltration and a livid scar on her knee. Biopsy of the scar and of the Kveim-Siltzbach test site showed sarcoid tissue. She responded to oral prednisolone; her chest $\mathrm{X}$-ray changes improved considerably but leaving some residual mid-zone fibrosis.

\section{Family VIII}

Case 16. This British Army Officer was found to have pulmonary sarcoidosis when aged 28 years, and this was accompanied by hypercalciuria and complicated by fatal cryptococcal meningitis at the Royal Postgraduate Medical School. An account of the clinico-pathological conference has been reported (British Medical Journal, 1969).

Case 17. The 28 year-old great-niece of Case 16 has recently developed Kveim-positive bilateral hilar lymphadenopathy, troublesome neurosarcoidosis, 
retinal involvement and hypercalciuria, all of which are responding to vigorous corticosteroid therapy.

\section{Family IX}

Case 18. A 34-year-old Trinidadian woman presented with bilateral parotid swellings shortly followed by bilateral anterior uveitis. Liver biopsy showed non-caseating granulomata. Tuberculin and Kveim-Siltzbach tests were negative. She responded to corticosteroids and became completely well after 3 years.
Case 19. Four years later, the 42-year-old Grenadan husband of Case 18 presented with a febrile illness and bilateral anterior uveitis. Chest radiography showed bilateral hilar lymphadenopathy and liver biopsy showed non-caseating granulomata. His tuberculin test, originally positive, converted to negative and his Kveim-Siltzbach test was negative. $\mathrm{He}$ is responding satisfactorily to corticosteroid therapy. 